\title{
ESTABLISHMENT OF DAMS AND EMBANKMENTS ON FRONTIER RIVER OF NORTH EAST PART OF INDIA: IMPACT ON NORTH-WESTERN REGION OF BANGLADESH.
}

\author{
M M Rahman ${ }^{1}$, M R Rahman ${ }^{2}$ and M Asaduzzaman
}

\begin{abstract}
India has built barrages on 17 more rivers in the east and northeast border with Bangladesh. Most of these dams and embankments act as the main barrier to flow water towards downstream like Bangladesh. As a result the rivers of Bangladesh that comes from India are falling in crisis of proper water. A study showed about 30 rivers of north-western part of Bangladesh gets very few water only due to dams and embankment made by India at the upstream of those rivers. Such massive water control projects of India are clearly a threat for a state that lies down of those. Unfortunately, and often ironically, national leaders of our country prefer to negotiate this sensitive matter rather than to make a strong protect of this inhuman and unethical activities. What is more astonishing news is that some time our state policy makers like to keep silent and avoid about it. India is always ready to controlling nature to serve economic development rather than addressing issues of trans-boundary and socio-environmental responsibilities. In fact, Indian plan to divert the water of Frontier Rivers is increasing at an alarming rate for Bangladesh. Here one thing is mentionable that is this types of project even harmful for India also. And peoples of north western state of India are in against of such harmful and high ambitious unnecessary project. Some time they also make a protest against it. Recently China and India are going to establish a large dam at the up Stream of Brahmaputra River. It would impair India's own plan to link approximately thirty of its own rivers, a project that is bound to affect the downstream riparian state of Bangladesh. As a result drastic fall in the water flow of Teesta during the lean season, especially in February and March will occur in more frequent and will seriously hampers irrigation in Bangladesh. Such international trans-boundary river development projects raise many important issues. They never consider the impact that will impose upon the down stream part like Bangladesh.
\end{abstract}

Key words: Dam, Embankment, Environment, Impact, India, Bangladesh.

\section{INTRODUCTION}

India holds a strong position in the list of dams building countries after US and China. In the year of 1947, there were around 300 large dams through out the country and number gradually increased by 2000. At present there are more than 4000 dams around India. Most of the dams are embankment dams meaning that they consists of a wall built across a river valley to impound water so as to form reservoir upstream and a system of spillways to by pass the wall so as to maintain normal river flow and convey water to a network of canal feeding irrigated region downstream. The neighboring country India has been directing forcible zeal to swallow Bangladesh through her hegemonistic policy in different ways since 40 years of our independence. For their own benefit, India wants to use river water during dry season and for this purpose they have taken a very high ambitious and expensive project to control the river by building hundreds of dams and embankments where necessary. The inter river linking project of India is doing this mission. In this way basically India wants to control the nature and establish dominancy on natural system of river flow. To fulfill their dream of interconnected river project, India has already taken necessary steps. Building different dams and embankment in the name of hydraulic power generation is the part of this project. Doyang, Kopili,

\footnotetext{
${ }^{1} \mathrm{PhD}$ fellow, Institute of Environmental Science, University of Rajshahi, Rajshahi-6205, Bangladesh

${ }^{2}$ Asst. Professor, Institute of Environmental Science, University of Rajshahi, Rajshahi-6205, Bangladesh

${ }^{3}$ Executive Director, Bangladesh Science Foundation, Dhaka, Bangladesh.
} 
Khandong, Loktak, Rammam-II, Ranganadi Rangit -III, Teesta Canal Power House- I, II, III, Teesta Low Dam Stage - IV,Umiam -III are the example of this project. Farakka barrage is another big project of India that creates a storm of dispute in international arena which is specially considered as the curse for Bangladesh. In May 1974 India has built it for the withdrawal of water of river Ganges 17 kilometers away from the border with Bangladesh.

India has taken now to build two dams at Tipamukh and Fulertal in the east on the river Barak that forms upper riparian of the Kushiara, Surma and mighty Meghna rivers of Bangladesh. The Teesta river is among several rivers flowing from the Himalayas into Bangladesh, providing a lifeline to both farming and ecology in both countries. These dams would jeopardise Bangladesh's economy or environment. The Joint River Commission of India is consider as the weapon of mass destruction Nearly 700 dams were built every ten years up to 1950. This number grew up rapidly after 1950s (M Sait). They construct dams and embankment in order to prevent flood, supply drinking and domestic water, to generate energy and irrigation purpose. But they never consider about the negative effect of these that impose on the neighbor country or beside area. India has built the Kosi dam of on river koshi which is a trans-boundary river flowing through Nepal and India. Both India and Nepal jointly work to establish this dam under kosi project to generate Hydrolic power. Due to this dam some river of north Bihar and west Bengal get very few water which cause a direct effect in Bangladesh western river. The kosi is known as the sorrow of Bihar. As kosi is one of the largest tributaries of the Ganga River so the dam built at the upstream of it also act as the barrier to get water of Ganga (Padma) river. The Gamdaki and Mahananda River are also affected by this dam. This type of problems is not only arising for the above mentioned dams but also for others as India has built. It should be kept in mind that, river flow is a natural system. For any artificial barrier on its way must create negative impact on society and environment. And for these we have to pay the compensation at any rate any how.

\section{Objectives}

The main objectives of this study are:

i) to know the existence of Indian dams and embankment at the border of Bangladesh

ii) To assess the impact of Indian dams and embankment on Bangladesh

iii) to evaluate the loss happened on Bangladesh due to dams and embankments

iv) to find out the causes of establishment of these dams and embankment.

\section{Study area}

The study area is a vast length of north, west and eastern part of Bangladesh where bad effect of Indian dams and embankment are deeply found. Due to the vast length of study area it has been constrict upon Rajshahi region Bangladesh as a token part of study area. This is known as Barind land where direct effect of Indian dams like Farakka Barrage is observed. It is a plenty river basin of Ganga(Padma). It is one of the major divisional head quarters of Bangladesh. It lies between $24^{\circ}$ $21^{\prime}$ North to $24^{\circ} 26^{\prime}$ North latitude and $88^{\circ} 28^{\prime}$ East to $88^{\circ} 38^{\prime}$ East longitude ((Rahman, 2006). It comprises a total area of 68.45 square kilometer. The population of the investigated area is about 7 lakh according to the census report of 2001 and its density is 7,969 persons per square $\mathrm{km}$. The temperature of this study area remain between $8.5^{\circ} \mathrm{C}$ to $25.25^{\circ} \mathrm{C}$ during winter season and in summer it fluctuate between $24^{\circ} \mathrm{C}$ to $42.25^{\circ} \mathrm{C}$ (Weather office, Rajshahi-2007).

\section{Justification of Research}

Due to location of downstream area, Bangladesh have to depend on sources (upstream area like India and Nepal) to get the water. For this availability, the source countries of natural water often play their role as the hierarchy like a big brother o Bangladesh. Ultimately Bangladesh has to pay the compensation or being silent victim for their ambitious projects. This country is facing loss on agricultural, fisheries, navigation, industries and many other sectors due to the effect of India dams and embankments. The environmentalists expressed deep concern if those project are implemented it could deprive Bangladesh of its share of the international river that supplies waters

to hundreds 
of water bodies in the region. As India and Bangladesh engage in a heated debate about an Indianplanned dam project, experts disagree about the consequences for Bangladeshi people and the environment. But scientific researches are found to measures the loss that occurs due to their river controlling projects. Rather we have to depend on foreign expert to assess the loss. As a result some time our state policy makers are misguided by foreign experts. And they disclose some vague data about these important issues. For these it is essential to do research about the above said title.

\section{MATERIALS AND METHODS}

The practical survey based this research conducted mainly field survey to assess the real feature that imposed due to dams and embankment at upstream area. Both primary and secondary data have been collected to conduct the research. Primary data have been collected from through and field survey. Secondary data have been derived from different sources like journals, books, published documents and the internet. For the field survey the researcher visited the research area and collected different information regarding the research title by consulting with the concerned authority. In case of secondary data some online article regarding the issues have been pursue here as the primary data was not sufficient. Findings of this study would have critical policy implication of this above mentioned issues and environmental threat alleviation thereby. The collected data are manipulated and makes a comparative study to find out the reality in case of loss that is occurring due to frontier dams and embankments of India that imposed gross negative effect on the downstream country Bangladesh. After collection of data and information about the Indian hydroelectric project based on frontier river of Bangladesh, a critical study have been done to measure the loss for Bangladesh specially at north western part.

State wise Indian major hydraulic projects at the border zone of Bangladesh

\begin{tabular}{|l|l|l|l|}
\hline $\begin{array}{c}\text { Sl } \\
\text { No }\end{array}$ & Name of project & Name of River & Name of State \\
\hline 1 & Lohit Dam Project & Lohit River & Arunachal \\
\hline 2 & Dibang & Dibang River & Arunachal \\
\hline 3 & Jiadhal Multipurpose Project & & Arunachal \\
\hline 4 & Tawang Chu HE Projects & Tawang Chu & Arunachal \\
\hline 5 & Nuranang Chu HE Project & Nuranang Chu & Arunachal \\
\hline 6 & Kosi dam project & Kosi river & Bihar \\
\hline 7 & Meghalaya Project & Wah Lyngkien & Manipur \\
\hline 8 & Tipaimukh HE Project & Barak & Manipur \\
\hline 9 & Dholaithabi Barrage Project & Dholaithabi & Manipur \\
\hline 10 & Myntdu HE Project & Myntdu & Manipur \\
\hline 11 & Jadukata M.P. Project & Jadukata & Manipur \\
\hline 12 & Pagladia M.P. Project & Pagladia & Asam \\
\hline 13 & Karbi Langpi HE Project & Borpani(Langpi & Asam \\
\hline 14 & Kulsi HE Project & Kulsi & Asam \\
\hline 15 & Kolodyne HE Project & Kolodyne & Mizoram \\
\hline 16 & Tuirini HE Project & Tuirini & Mizoram \\
\hline 17 & Tuivawl HE Project & Tuivawl & Mizoram \\
\hline 18 & Tuichang HE Project & Tui & Mizoram \\
\hline 19 & Kalasi Barrage & Yamuna & Tripura \\
\hline 20 & Jadukata Dam project & Jadukata & Meghalay \\
\hline 21 & Farakka & Ganga & West Bengal \\
\hline
\end{tabular}




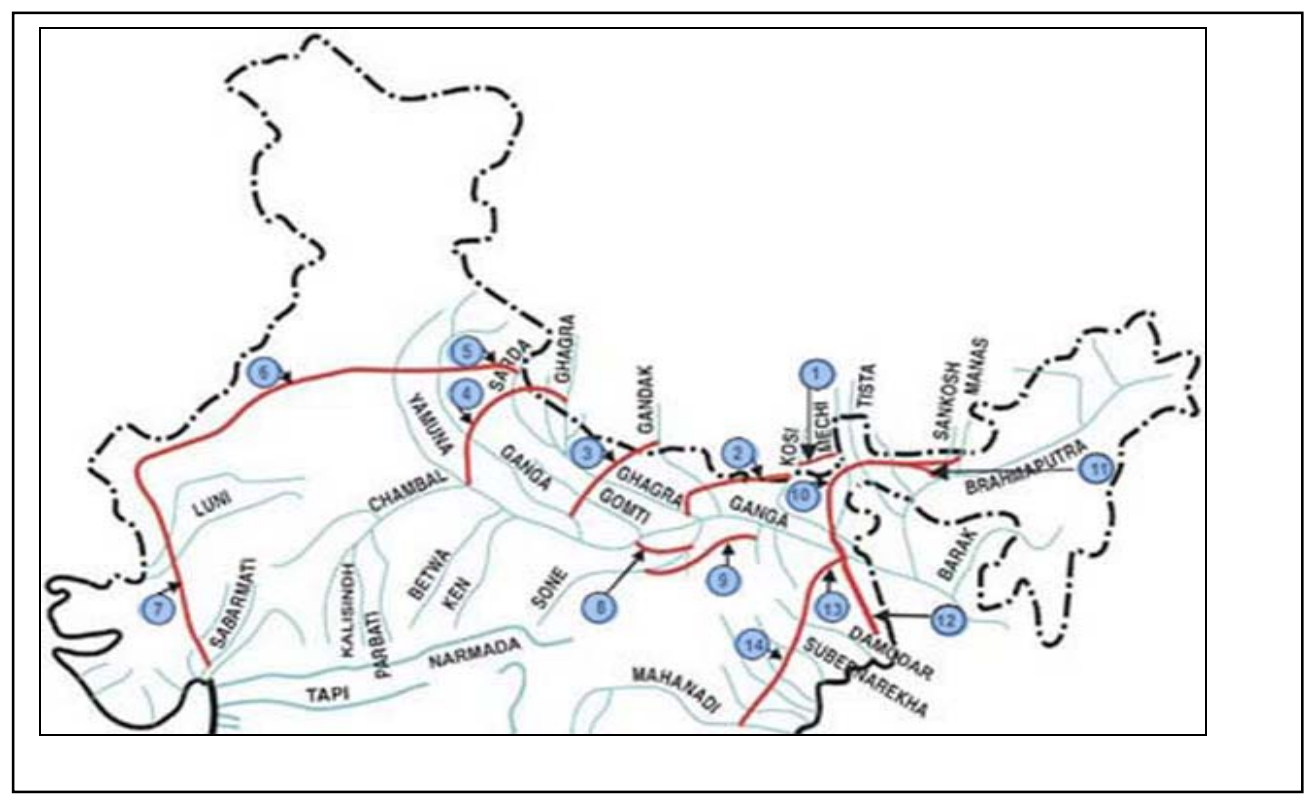

Fig-1 Indian dams and embankment location map (North-East)

\section{Brief Discussion on Farakak and Tipaimukh \\ Farakak Barrage}

Farakka is not only the name of the barrage on the Ganges, it has been a symbol of environmental havoc in the national life of Bangladesh (Miah,1996). Defying international law and disregarding the rights of the lower riparian country, India built a dam in 1975 on the Ganges River just 11 miles from the border of Bangladesh. The dam diverted Ganges water into India's Hugli River, causing tremendous hardship to Bangladesh. India's Farraka dam added a man-made disaster to the natural ones that routinely beset Bangladesh. Ever since India diverted the waters to its side of the border the Bangladesh side has been devastated. The dam has put a serious strain on many aspects of Bangladeshi daily life, from rice paddies and paper mills to river ferries and water wells. One researcher estimates that the water diversion causes annual losses of more than $\$ 4$ billion for Bangladesh. It has been noticed that some villagers of the study area have to dig wells as deep as 200 feet to obtain drinking water. Silt has been the main problem throughout the entire Ganges River delta on both sides of the border. However, the arbitrary building of the Farraka dam has caused untold misery to thousands of people who depend on Ganges (Padma) waters. Over the past 25 to 30 years, the dam also has ruined the region's ecology. Experts' estimate that it will take 50 to 60 years to repair environmental damage, and that will require great effort and extensive international assistance which is a mammoth task for a poor country like Bangladesh.

\section{Tipaimukh Dam}

The aggression of India in case of water is going on tremendously. When the people of Bangladesh passing their days with a great misery of barrage of death Farakka, India further start a news dams know as Tipaimukh. The project envisions a $390 \mathrm{~m}$. long, $162.8 \mathrm{~m}$. high earthen-rock filled dam across the Barak, $500 \mathrm{~m}$. downstream of the confluence of the Tuivai and the Barak on the ManipurMizoram border. The dam will be at an altitude of about $180 \mathrm{~m}$. above mean sea level with a maximum reservoir level of $178 \mathrm{~m}$. The dam was originally designed to contain floodwaters in the lower Barak valley but hydro power generation was later incorporated into the project. The project will have an installation capacity of $1500 \mathrm{MW}$ and a firm generation of $412 \mathrm{MW}$. The dam will permanently submerge an area of $275.50 \mathrm{sq}$. km. in the state of Manipur, India. While Hydroelectric projects are typically considered greener than other power generation options in short term, it has 
significant long-term impact to the environment like changes in the ecosystem, destroying nearby settlements and changing habitat conditions of people, fish and wildlife. Especially in the densely populated countries like India and Bangladesh, where rivers are lifelines, projects like Tipaimukh will create adverse effect to a huge number of population and their habitats.

No wonder right from the start this project faced protests from potentially affected people in India, and from the downstream neighbor Bangladesh. The people of Manipur have been fighting legally to stop the project but have so far been unsuccessful. The Indian government is going ahead with the plan. It is being said that this dam is being built for the greater interest of the people of North Eastern India by controlling the rivers to prevent flood in the Asam region and producing electricity. According to international laws, without the consent of the downstream river nation and causing environmental damage no one country can control the multi-nation rivers alone. But the sad fact is that nobody cares for these international laws. The might is always right while interpreting these laws. As Bangladesh is not so powerful like India in economic and military contexts we always are pushed aside. India has built barrages on 17 more rivers in the east and northeast border with Bangladesh.

\section{Projects under Construction}

Beside these projects, there are some more projects for power generation which are under construction at the north eastern region of India

Projects under construction in North -Eastern region of India.

\begin{tabular}{|l|l|l|}
\hline Name of the Project & Capacity (MW) & State \\
\hline Doyang & 25 & Nagaland \\
\hline Karbi Langpi (Lower Borpani) & 100 & Assam \\
\hline Kopili Stage II & 25 & Assam \\
\hline Likim- Ro & 24 & Nagaland \\
\hline Loktak Downstream & 90 & Manipur \\
\hline Teesta Stage V & 510 & Sikkim \\
\hline Tuirial & 60 & Mizoram \\
\hline Tuirini & 35 & Mizoram \\
\hline Tuivall & 35 & Mizoram \\
\hline Umiam- Umtru St-V & 30 & Meghalaya \\
\hline
\end{tabular}

Source: CEA, NEEPCO-2005

\section{A brief discussion of some projects \\ Doyang}

Doyang is a rockfill dam on the Doyang River, a tributary of Brahmaputra, $30 \mathrm{~km}$ from Wokha in Nagaland. The catchment area at the dam is 2,606 sq km. The height of the dam is $92 \mathrm{~m}$ and the reservoir has a live storage capacity of 535 MCM. With mean annual inflow of 1,355 MCM, Doyang power house has 3 units of 25 MW each and has a firm power of 21 MW. North Eastern Electric Power Corporation (NEEPCO) commissioned the project in 2001.

\section{Kopili}

This project consists of Umrong dam on Umrong River, a tributary of Brahmaputra River. The power house is located at a distance of $70 \mathrm{~km}$ from Lanka in Assam. The catchment area at the dam is 1,318 $\mathrm{km}^{2}$. The height of the dam is $30 \mathrm{~m}$. The reservoir has a live storage capacity of $55.5 \mathrm{MCM}$ at FRL $609 \mathrm{~m}$ and the MDDL is at $592.83 \mathrm{~m}$. Kopili power house has 4 units of $50 \mathrm{MW}$ each, with mean 
annual inflow of 2,860 MCM. NEEPCO commissioned the project during 1988-97 which has a firm power of $55 \mathrm{MW}$.

\section{Khandong}

This dam on Khandong River, a tributary of Brahmaputra, is located at a distance of $70 \mathrm{~km}$ from Lanka in Assam. The height of the dam is $66 \mathrm{~m}$ and its catchment area is $1,256 \mathrm{~km}^{2}$. The reservoir has a live storage capacity of $129.5 \mathrm{MCM}$ at FRL $719.3 \mathrm{~m}$; the MDDL is at $704 \mathrm{~m}$. Khandong power house has 2 units of $25 \mathrm{MW}$ each, with mean annual inflow of 2,860 MCM and provides firm power of 13 MW. NEEPCO commissioned the project in 1984.

\section{Loktak}

Loktak Hydroelectric station involves a barrage, namely Ithai barrage, near Loktak Lake, $39 \mathrm{~km}$ from Imphal in Manipur. The catchment area at the barrage is $1,000 \mathrm{~km}^{2}$. The height and length of the barrage are $11 \mathrm{~m}$ and $59 \mathrm{~m}$ respectively. The pond has a live storage capacity of 397 MCM at maximum water level $768.5 \mathrm{~m}$ and the minimum water level is at $766.2 \mathrm{~m}$. Loktak power house has 3 units of $35 \mathrm{MW}$ each, with mean annual inflow of 679 MCM. It has a firm power of $42 \mathrm{MW}$. NHPC commissioned the project in 1983.

\section{Rammam II}

This hydroelectric station uses water from Rammam and Lodhama weirs constructed on Rammam River and its tributary Lodhama Khola; these are the tributaries of Teesta River. The power house is located at a distance of $77 \mathrm{~km}$ from Darjeeling, West Bengal. The intercepted catchment area is 209 $\mathrm{km}^{2}$. Four units of $12.75 \mathrm{MW}$ each have been installed with a firm power of $14 \mathrm{MW}$. West Bengal State electricity Board commissioned the project in 1995-96.

\section{Ranganadi}

A concrete gravity dam has been constructed on Ranganadi River, a tributary of Brahmaputra River, $50 \mathrm{~km}$ from Zir City in Arunachal Pradesh. The catchment area at the dam is 1,894 km². The height of the dam is $68 \mathrm{~m}$ and the reservoir has a live storage capacity of $21.28 \mathrm{MCM}$ at FRL $567 \mathrm{~m}$; its MDDL is at $560 \mathrm{~m}$. Doyang power house has 3 units of $135 \mathrm{MW}$ each, with maximum and minimum annual inflow of 5,080 and 2,048 MCM respectively. It has a firm power of 166 MW. NEEPCO commissioned the project in 2002.

\section{Rangit III}

Rangit III hydroelectric station was constructed in the year 2000 by NHPC on Greater Rangit River, a tributary of Teesta River. The dam is located at a distance of $130 \mathrm{~km}$ from Siliguri in South Sikkim District. The catchment area at the dam is $979 \mathrm{~km}^{2}$ and the dam is $47 \mathrm{~m}$ high. The reservoir has a live storage capacity of 1.175 MCM at FRL $639 \mathrm{~m}$ and the MDDL is at $627 \mathrm{~m}$. The power house has 3 units of $20 \mathrm{MW}$ each, with mean annual inflow of $0.696 \mathrm{MCM}$. It has a firm power of $39 \mathrm{MW}$.

\section{Teesta Canal Power House I, II, III}

Three power houses have been constructed on Teesta canal, namely Teesta PH I, II, and III. Teesta canal emerges from Mahananda barrage, which has been constructed on Teesta River, a tributary of Brahmaputra River in Siliguri, West Bengal. The Power houses have been constructed on the canal at $5 \mathrm{~km}, 21 \mathrm{~km}$ and $31 \mathrm{~km}$ from barrage, near Siliguri town in Jalpaiguri District, West Bengal. The catchment area at the Mahananda barrage is $675 \mathrm{~km}^{2}$. The design flood of Mahanada barrage is 2,265 $\mathrm{m}^{3} / \mathrm{s}$. All the three power houses have 3 units of $7.5 \mathrm{MW}$ each. WBSEB commissioned the project in 1997-99.

\section{Teesta Low Dam Stage - III Hydroelectric Project}

It is being constructed on Teesta River in Darjeeling distt. (W.B). It is located near New Jalpaiguri. The project will have $32.5 \mathrm{~m}$ high barrage and the power plant will have installed capacity of $4 \times 33$ MW or 132 MW to annually generate 594 MU in a 90\% dependable year. This project is estimated to cost Rs. 770 crore. Work is in progress and is anticipated to be completed by March 2008. 


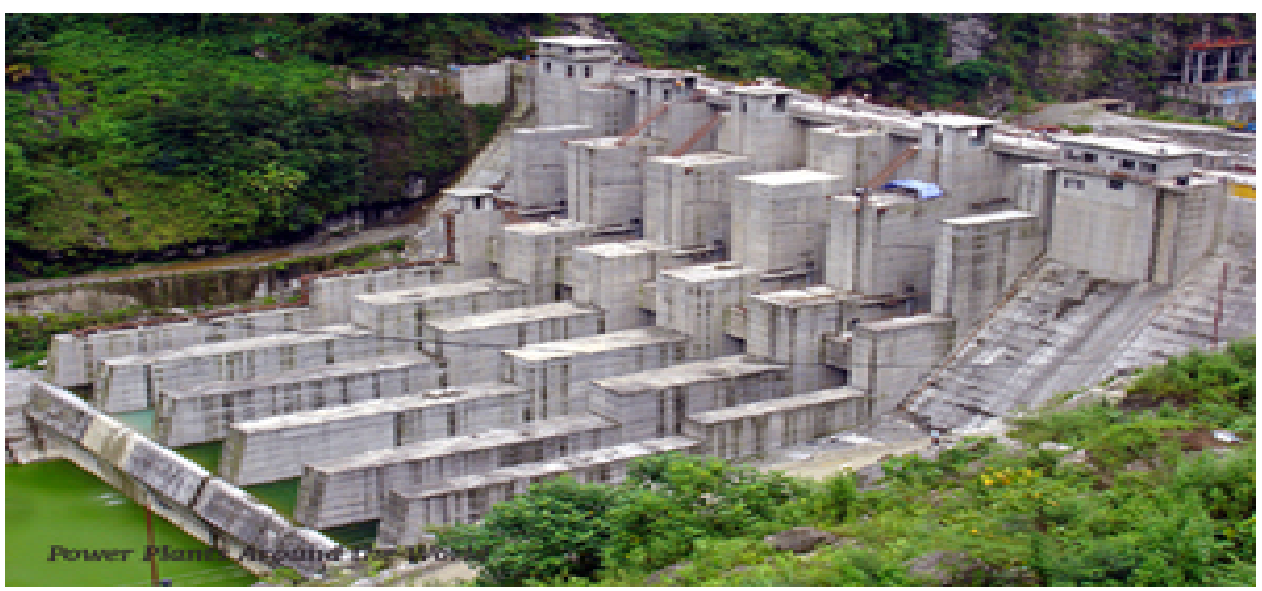

Fig-2 Teesta Low Dam Stage - IV, source -NHEPC-2002

\section{Teesta Low Dam Stage - IV Hydroelectric Project}

This project is under construction near Siliguri town in Dist. Darjeeling, West Bengal. Here, a $45 \mathrm{~m}$ high concrete gravity dam will be constructed. The catchment area for the project is 8,021 sq. km. With FRL of $182.25 \mathrm{~m}$ and MDDL of $179.00 \mathrm{~m}$, the reservoir has a gross storage of 36.63 MCM and live storage of 7.91 MCM. For power generation, the underground power house will have Kalpan Turbines, 4x40 MW each which will work at gross head of $25.8 \mathrm{~m}$. Its annual generation is likely to be $720 \mathrm{MU}$ (90\% dependable year). Work is expected to be complete by September 2009 at a cost of Rs.1,061 crore.

\section{Umiam III}

This is the third in the series of projects with Umiam I of 36 MW and Umiam II of 18 MW capacity. Umiam III hydroelectric project consists of Kyrdemkulai concrete gravity dam on Umiam \& Umtru Rivers, tributaries of Brahmaputra. The power house is located at a distance of $52 \mathrm{~km}$ from Shillong in District Ri Bhoi of Meghalaya. The catchment area at the dam is $520 \mathrm{~km}^{2}$ and its height is $27.5 \mathrm{~m}$. The reservoir has a live storage capacity of 2.78 MCM at FRL $681.23 \mathrm{~m}$ and the MDDL is at 675.58 m. Umiam III power house has 2 units of $30 \mathrm{MW}$ each. It has a firm power of $16 \mathrm{MW}$.

\section{Umiam IV (Nongkhylle)}

Umiam IV hydroelectric project consists of Nongkhylle dam across Umtru River. The power house is located at a distance of $55 \mathrm{~km}$ from Shillong in District Ri Bhoi of Meghalaya. The catchment area at the dam is $150 \mathrm{~km}^{2}$. The height of the dam is $43 \mathrm{~m}$. The reservoir has a live storage capacity of 4.94 MCM at FRL $503 \mathrm{~m}$ and the MDDL is at $496 \mathrm{~m}$. Umiam IV power house has 2 units of $30 \mathrm{MW}$ each, with mean annual inflow of 52 MCM. It has a firm power of 15 MW. Meghalaya State Electricity Board commissioned the project in 1992.

\section{RESULT AND DISCUSSION}

The research work specially emphasize on to find out the environmental impact of Indian dams and embankment on Bangladesh as well as to estimate a gross loss and to depict the suffering that is occurring due to these water barriers. The study found these in different aspect including political and social economical and environmental loss.

\section{Impact on Environment}

Bangladesh has three of the world's most powerful rivers passing through its country - the Ganges, the Meghna and the Brahmaputra, but still suffering a lot due to crisis of water. This is due to establishment of Indian dams and embankments on frontier river of north east part. Most of the rivers of Bangladesh get water from the frontier river of India. If India is continue to construct the dams and embankment at the upstream of Bangladesh than a severe environmental havoc will be occur for Bangladesh. We can imagine the loss only for Tipaimukh dams. It will show what a miserable condition is waiting for Bangladesh due to Indian hydroelectric dams project. Bangladesh gets 7 to 8 percent of its total water from the 
Barak in India north-eastern states. Millions of people are dependent on hundreds of water bodies, fed by the Barak, in the Sylhet region for fishing and agricultural activities. Bangladesh is internationally acknowledged for its biodiversity wealth, and as such, is of immense significance for the country and, indeed, the planet. Environmentalists are fear that the Tipaimukh dam would ultimately dry up the Meghna river in the greater Sylhet region and nearly districts. The dam will kill all common rivers of the country particularly the Meghna, the biggest river of the country. The construction of the dam when will complete in 2012 would bring about a major disaster for Bangladesh, virtually drying up the Surma and the Kushiara rivers in winter season, which water most of the north-eastern regions of Bangladesh. The Tipaimukh dam would seriously affect not only agriculture, particularly in winter, but is also going to bring about negative ecological and environmental changes in vast areas in both Bangladesh and India. Among the common rivers, the most rivers affected by Indian barrages and their networks of canals, reservoirs and irrigation schemes are the Ganges, the Meghna and the Teesta. With the Tipaimukh dam now underway, India would be diverting river waters from its north to its south and east, thereby putting Bangladesh under serious stress. The environmentalists in Bangladesh have held many talks on the adverse impact of the proposed dam. They say the dam would dry up the river and the water bodies in the downstream, leaving millions homeless and jobless.

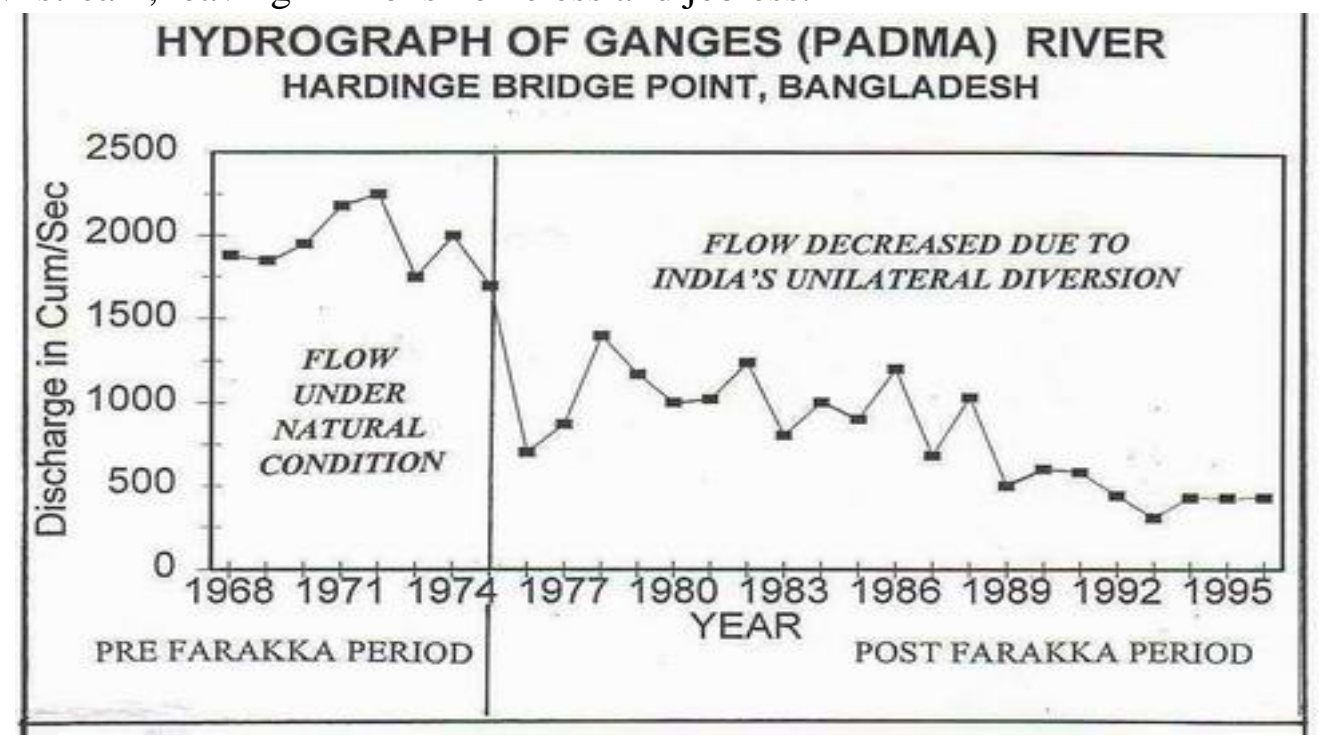

Fig-3 Comparative Hydrograph of water flow at Padma river near Hardinge Bridge

Source: NHEPC-2002

\section{Arsenic Problem in Bangladesh acute due to Upstream Dams}

Arsenic problem in Bangladesh has become acute due to man-made dams in the trans-border Rivers like the Farakka and Tista barrages that impede the natural river flow. The natural river flows have to be resumed by removing the river-dams to solve the arsenic problem. Bangladesh is a disaster-hit country. Natural disasters and man-made disasters hit the country frequently. Arsenic is one of the man-made disasters, in present context of Bangladesh crops and industrial production depend on the underground water, but approximately 10 million tube-wells are affected by arsenic across the country. More than 30 million people of the country are drinking the arsenic contaminated water. In addition to the Farakka barrage, the 17 dam/barrages that India has constructed may have significant influence on the arsenic and other environmental disasters in Bangladesh (Husain 2000). There is a strong correlation between the post Farakka disasters and the Farakka barrage. The hydrograph shows the annual Pre Farakka discharge (1968-1974), the discharge under natural condition and the annual Post-Farakka discharge (1975-1996), the discharge because of India's unilateral diversion violating 
the natural as well as international river laws have caused many disasters both down stream and up stream. The construction and commission of Farakka barrage, India's 23 years of unilateral diversion of water, the construction of other dams/barrages in common rivers of Bangladesh and India the following disasters in Bangladesh are believed to have been caused by or aggravated by different hydroelectric projects.

\section{Direct Impact of Dam's Project}

Dams and embankment has both direct and indirect impact on earth and environment. The direct impacts are as follows

1. Displacement of people especially of vulnerable minorities only for Tipaimukh dam 1,461 Hmar families will be directly displaced from Manipur of India

2. Vast forestland to be inundated along with the biodiversity

3. Plenty of agricultural lands will loss fertility due to experience salinity.

4. Possible earthquake could have devastating effect

5. Possible river drying and devastation of wetland (Haor)

6. Possible flood in summer/winter in lowlands causing damage to agriculture

7. Reduction in agricultural products due to insufficient water for irrigation.

8. Transportation problems: boats rendered useless; tributaries are dry during dry season

9. Increased salinity threatening crops, animal life drinking water, and industrial activities in southwest Bangladesh.

10. One fourth of the fertile agricultural land will become wasteland due to a shortage of water

\section{Impacts on Health}

There are some impact of dams are focused on health. Large scale confiscation of water raises contact to several vector born diseases like filariasis, malaria, schistosomiasis and blindness (Shaha, 1983). One of the most serious and least-studied consequences of large dams are the long-term health impacts due to drastic changes in the ecological balance, displacement and loss of livelihood, sudden alterations in the demographic character of the area and movements of large numbers of people involved in construction and other activities. It is a well-known fact that the construction of dams invariably destroys the natural riverine ecosystem. As a result, it affects the habitat of rare and endemic species of flora and fauna. Construction of a high dam disturbs river functions, causes floods, dries out downstream flood plains, devastates riverside ecology, obstructs the migratory path of fish and other aquatic fauna, prevents the exchange of micro-nutrients and silt between the upper and lower reaches of a river and has an overall adverse affect on the riverine food chain.

\section{Impact on Ground Water}

The long-term impact of Indian frontier dams on Bangladesh is noticed on ground water. Due to shortage of surface water on river, lake and wetland the ground water table has ultimately fall. It is keenly observed during lean period. The north-western part of Bangladesh is deeply facing this problem. The same crisis is found at the southern part of Bangladesh. Beside these, there is another problem arise that is increase of salinity to the drinking water as the aquifer achieve salinity more. The fall of ground water table lead numerous problems which are a cause of shortage of drinking water. The underground water level of 8 districts of northern part of the country including Dinajpur is falling gradually posing a threat to Irri-Boro farming. About 30 percent tube wells in the area have become inoperative for want of water in the underground level. The farmers are resinking their shallow tube wells by digging soil from two or five meters depth in some areas of the region to reach the underground water level to irrigate their paddy fields. A source said that the water reserve in the upper part of underground water level has been exhausted and the next level has gone down by 10 to 15 feet. The worst affected districts are Dinajpur, Thakurgaon, Kurigram, Rangpur, Lalmonirhat, Nilphamari and Gaibandha. Some 500 shallow and deep tube wells out of 15000 and more than 1000 tara pumps out of 1500 remained inoperative in the district for want of sufficient underground water 
(NGO report-2010). The problem persists mainly in the dry season when farmers irrigate their cropland. Farmers make a pit five to six feet below the surface and put the shallow pump there to draw groundwater. During 2006-07 irrigation survey report of the government, around 10 million farmers have overwhelming dependence on STWs for almost 70 percent of 47.8 lakh hectares of irrigated cropland in the last Rabi season. The groundwater zoning map of BADC prepared in 2006 shows that a record high of 78 percent irrigated cropland in Pabna has become critical for STW operation (Hasan-2010).

\section{Impact on Ecology}

Dams, like all other man-made infrastructures, are actually disasters for ecological balance of a region. When a dam creates its own rule of ecology, the existing one is demolished. In this particular case, there is a couple of major ecological balance shifting. In Bangladesh, it could potentially damage a vast natural wetland, known as haor. Shift in ecological balance does not always mean a problem in short term. It causes problem in the long term. Any flood moderation structure would cause damage to ecology - be they embankments or dams - as floods are part of ecological balance. If the river gets little water than its ultimate impact will impose on wetland. The wetland will dries up due to barrier of river flow like dams and embankment. The Sunamganj, Habiganj and Moulvibazar, Sylhet, Kishoreganj and Netrokona districts are the haor zone of Bangladesh maintaining the major role to keep the environmental and ecological balance. These haor will directly affect due to Tipaimukh dam. As a result the ecology and ecosystem of Bangladesh will fall in great threat.

\section{Spread of Arsenic}

Bangladesh is located down gradient from West Bengal. During wet season the country receives huge amounts of surface water and pollution carried by rain water from the Indian Subcontinent. The groundwater flow directions of major aquifers in the six districts of West Bengal are to the south and south easterly direction towards Bangladesh. Being located down gradient, Bangladesh is receiving huge quantities of arsenic contaminated water from West Bengal (Dipankar et al, 1996). The migration of arsenic contaminated water from West Bengal to the Ganges delta of Bangladesh may have increased the concentration of arsenic in both soil and groundwater. A contributing factor to the groundwater arsenic poisoning in Bangladesh may have been India's 23 years of unilateral diversion of water from the Ganges river (Miah,1995). India's continued diversion of 1,133 cum/sec out of 1728 cubic meter per second for about two decades during the dry season, has made serious impacts on the Ganges basin ecosystems. Water level in ponds has dropped about 60 percent both in quantity and duration.

\section{Exacerbate Tensions between Two Countries}

The establishment of Indian dams and embankment in unilateral interest ignoring the effect of neighboring country increase exacerbate tension between two countries India and Bangladesh. The only Farakka barrage arises as an unending issue between two countries. India again provoked Bangladesh by unilaterally diverting water at Farakka, causing a severe water shortage in Bangladesh (Tanzeema, 2001). In 1975, the year that India completed construction of the Farakka barrage and was given consent by then-Bangladeshi Prime Minister Sheikh Mujibur Rahman to run a ten-day test of its operation. The Indian government not only completed the test run, it also made the provocative decision to continue diverting the Ganges flow after the expiration of ten days agreement (Jacques, 2000). After that the conflict between this two countries is establish. The border between India and Bangladesh in this area is not settled. An aggressive behave in this area may exacerbate tensions between the countries.

\section{CONCLUSION}

Bangladesh has been turning into a desert over the years, due to the river linkage programmes of India that started off with the Farakka barrage. Bangladesh has got some international rivers in the country. 
Most of these rivers crisscrossed millions of acres of land in India before their arrival in Bangladesh. Both Bangladesh and India have equal rights over the waters of these rivers. But, ignoring the rights of Bangladesh, India has been constructing barrages on many river systems. In the past, India diverted water from the Padma and the Tista by constructing dams in their Indian parts. The hinterland of the two mighty rivers has turned barren for want of water. Now the Tipaimukh barrage is another death trap for Bangladesh. If India goes on with this project, the Meghna - Surma river systems will be reduced into mere brooks. It will caste a gloomy spell over the whole Sylhet region by affecting agricultural yield, navigability and industrial establishments downstream. Moreover, it is no longer a secret that, despite building 3,600 large dams of its own, India has failed to fulfill pledges of promised development to its own people. The World Commission on Dams Report puts the figure of people affected by the dams at about 600 million worldwide over the last fifty years. Every year, the promotion of high dams affects two million people globally, in addition to environmental costs, so Bangladesh, Nepal, Myanmar must not remain upbeat about reaping maximum advantages from high dam. It must not keep quiet but should assess the loss and protest such kind of inhuman deeds.

Building Dams can provide a numerous benefit to the economy and local and regional development from being sufficient in energy, flood control, land improvement, drinking water, and water transportation to irrigation. However, the benefits outweighs the potential damage ranging from displacement of people and established communities, environmental and ecological catastrophes including damaging to habitat of wild life and flora and fauna, depletion of fishing stocks, archaeological and historical places in company with geological and topographical places that are rare with their exceptional beauties, disappear after lying under the reservoir and not to mention the security and boarder issues both domestically and internationally. So our policy makers ought not to forget the real issue, and they should concern about environment and existence of Bangladesh. The natural groundwater flow that existed prior to 1975 should be restored by removing all dams/barrages that India constructed in the common rivers of Bangladesh and India. The removal of dams/barrage and the dredging of rivers will decrease the number of disasters in both Bangladesh and in the upstream region of India. The mega scheme could be disastrous for the 185 million people of India's North East and Bangladesh. There is also serious concern about the earthquake disaster. The region's regular earthquakes that can hit 8.0 on the Richter scale, can destroy the civilization and symbol of living. So it is high time to com forward against any establishment of dams and embankment on river. The neighbor country India should change their obduracy mode and abide such kind of less necessary activities for the greater welfare of man and environment.

\section{REFERENCES}

Tashi Tsering, 2004. Let the Brahmaputra flow: Tibet's Environment and Development Digest,January Issue- 4.India, pp21-25

M. Sait, T. et al. 2006. Positive and Negative impacts of dams on the environment, Ankara, Turkey. Rahman, M. Moshiur (2006) Drainage Pattern of Rajshahi Metropolitan City and Its Impact on Human Health. Thesis paper, Department of Geography and Environmental Studies, University of Rajshahi. Rajshahi. pp 41-55.

Husain,T, Meer, 2000. World's largest Man-Made Arsenic Disaster in Bangladesh and Sustainable Solution to the Problem", Emporia State University Kamsas, USA

Miah M.A. 1995, "Farakka the Death Trap" Social Journal,University of Arkansas, U.S.A.pp36-39

Miah M.A. 1996, The Water Crisis in Bangladesh A challenge to Integrated Water Management in Urban Areas, U.S.A.pp28-29 
Hasan, Khandakar Fazle.2010. Chief geologist of Bangladesh Agriculture Development Corporation, BADC, Dhaka

Shaha, K.C. 1983, Journal of School of Tropical Medicine, Calcutta, India Das, Dipankar et al, 1996, west Bengal, India,p25

Tanzeema, S. \& I.M. Faisal, 2001. Sharing the Ganges: a critical analysis of the water sharing treaties, Water Policy 3 (2001) 13-15.

Jacques, Kathryn. Bangladesh, India, and Pakistan: International Relations and Regional Tension in South Asia. Macmillan Press, 2000.

Central Water Commission, India-1945, p-13

CEA, Central Electricity Authority, North Eastern Electric Power Corporation-India, 2005

NHEPC, National Hydro-Electric Power Corporation, Siliguri, India, 2002 